the possibility of cooperation between the two groups. Before the conference began the Hungarian historians sent written "Proposals for Cooperation between Austrian and Hungarian Historians" to their numerous Austrian colleagues who were present at the meeting. These proposals served as a basis for the discussions. Among numerous proposals for common publications, the exchange of scholarly works and scholarly personnel, joint conferences, etc., the plan to prepare an edition of the protocols of the joint ministerial council is especially worthy of notice. While the meeting was still in progress, General Director Dr. Gebhard Rath stated that the Austrian State Archives were willing to cooperate in preparing such an edition. The Arbeitsgemeinschaft Ost, in Vienna, which has long been known for its lectures and publications, officially changed its name to Österreichisches Ost- und Südosteuropainstitut.

The Arbeitsgemeinschaft für Geschichte der Arbeiterbewegung in Österreich, in Vienna, arranged an international symposium on the topic, "Austria-Hungary and the Internationals," which was held in Vienna on September 7-9, 1964. The majority of papers were read by persons from the succession states of the former Austro-Hungarian monarchy. As the symposium was a workers' meeting, only a small group of specialists was invited to attend it.

The eighth annual Austrian historical conference was held at St. Pölten, in Lower Austria, on September 14-18, 1964. The lectures and discussions were devoted more to national history than to any other subject. Among the topics dealing with recent history discussed at the meeting, J. R. Salis, of Zürich, reported on "Research and Writings on the History of Recent Times;" and R. Lorenz, of Vienna, spoke on "Historical Science, Biography, and Generation."

\title{
SPECIAL PUBLICATIONS
}

In the fall of 1964 the Arbeitsgemeinschaft Ost, in Vienna, brought out a new German edition of Robert Kann's The Multinational Empire in its publication series.

The Committee for the History of the Austro-Hungarian Monarchy 1848-1918 added a second volume to its publication series: Felix Höglinger's Jaroslav Clam-Martinic. Vol. III (Erich Prokopowitch's Die rumänische Nationalbewegung in der 
Bukowina und der Dakoromanismus) is now in press.

\section{PERSONAL}

In February, 1964, Docent Walter Goldinger, chief archivist in the Staatsarchiv, was appointed associate professor of Austrian history and methodology at the University of Vienna.

In the spring of 1964 Ferdinand Maass, formerly ausserordentlicher professor for medieval and modern Church history at the Catholic theological faculty at the University of Innsbruck, was promoted to professor on the same faculty.

During the summer of 1964 Fritz Fellner, formerly of the University of Vienna, was appointed professor of modern history at the University of Salzburg.

In the fall of 1963 Prof. Hugo Hantsch was awarded the Grossen Verdienstkreuz of the German Republic.

Since the fall of 1963 first class Austrian crosses of honor for arts and sciences have been awarded to Erich Swoboda, Friedrich Walter, and Oskar Regele.

Prof .August Maria Knoll, professor of sociology at the University of Vienna, an expert on recent Austrian history and culture, died in Vienna on December 24, 1963.

\section{NEWS FROM HUNGARY}

\section{HABSBURG CONFERENCE IN BUDAPEST}

The Historical Institute of the Hungarian Academy of Sciences sponsored its third international conference on the history of the Dual Monarchy in Budapest from May 4-9, 1964. The previous conferences were held in 1954 and 1959. The general theme of the conference was "The Historical Problems of the Austro-Hungarian Monarchy, 1900-1918." There were forty-five scholars present from ten countries-Austria, Bulgaria, Czechoslovakia, France, East and West Germany, Italy, Jugoslavia, Rumania, the Soviet Union, and the United States.

The conference was opened by Erik Molnár, who greeted the participants and guests and then stressed the importance of the problems to be discussed. Thereafter the conference turned to the issues to be examined. The first day was devoted to an 